Studia Oecumenica 17 (2017)

DOI: $10.25167 / \mathrm{SOe} / 17 / 2017 / 365-380$

RADOSŁaW CHAŁUPNIAK

Wydział Teologiczny UO

\title{
Meandry wychowania ekumenicznego
}

\author{
Meanderings of Ecumenical Education
}

\begin{abstract}
This article in a synthetic way presents the complex issue of ecumenical education of religion, fluctuated between 'catechesis' and 'religious studies'. Catechesis is a basic teaching of the Church about salvation and was understood as an integral and systematic process of upbringing in faith. The term ,religious studies" was used as a form of the communication of knowledge about religion, as teaching about religion or religions with no stress on any of them, without trying to make any personal references, treating religion solely in a horizontal way, as a phenomenon related to human life. Pedagogy of religion done without a specific confession, specific denomination is a peculiar form of secularisation, regardless whether it is intended or not. Such pedagogy of religion becomes paradoxically a science located outside a confession, which serves its development as a pedagogical theory, not a specific practice of education. Religion is treated as a universal phenomenon having its share in obtaining a fullness of humanity. Contemporarily offered pedagogy of religion can not be identified with the Catholic pedagogy or a pedagogy of any Christian church.
\end{abstract}

Keywords: evangelical pedagogy of religion, ecumenical education, ecumenical dimension of catechesis, the school teaching of religion, religious studies.

\section{Streszczenie}

Artykuł ukazuje w sposób syntetyczny szereg zagadnień związanych z ekumenicznym wychowaniem religijnym, znajdującym się pomiędzy „katechezą” a „religioznawstwem”. Katecheza jest podstawowym nauczaniem danego Kościoła dotyczącym zbawienia i jest rozumiana jako integralny i systematyczny proces wychowania wiary. Termin ,religioznawstwo" był używany jako forma przekazu wiedzy na temat religii, nauczanie o religii czy religiach, bez tworzenia osobistych odniesień, pozostając na płaszczyźnie horyzontalnej, traktując religię jako fenomen związany z ludzkim życiem. Pedagogika religii uprawiana bez odniesienia do konkretnego wyznania, konkretnej wiary jest specyficzną formą sekularyzacji, niezależnie od tego, czy jest ona zamierzona, czy nie. Taka pedagogika religii staje się paradoksalnie nauką ulokowaną poza określonym wyznaniem, co służy jej rozwojowi jako teorii pedagogicznej, a nie określonej praktyce wychowania. Religię traktuje się jako uniwersalny fenomen posiadający udział w osiąganiu pełni człowieczeństwa. Proponowana pedagogika religii nie może być utożsamiana z pedagogiką katolicką ani pedagogiką żadnego z chrześcijańskich Kościołów. 
Słowa kluczowe: ewangelicka pedagogika religii, ekumeniczne wychowanie, ekumeniczny wymiar katechezy, szkolna lekcja religii, religioznawstwo.

Nawet w obliczu wzrastającego pragnienia chrześcijan różnych wyznań, by jedność uczniów Jezusa nie była wyłącznie wzniosłym wyzwaniem, lecz stawała się czymś konkretnym, sprawdzalnym i wyraźnym, nie wolno zapominać, że istniejące podziały nie są wyłącznie kwestią umowną, lecz dotyczą bardzo głębokich odniesień zarówno na płaszczyźnie treści wiary (dogmatyki), jak i jej życiowych konsekwencji (moralności, duchowości, liturgii, prawa kościelnego, ewangelizacji i katechezy). Płytko rozumiany ekumenizm, połączony często z religijną ignorancją, subiektywizmem i relatywizmem, prowadzi do zaniku poczucia odrębności wyznaniowej, do zobojętnienia wobec istotnych skądinąd różnic wyznaniowych ${ }^{1}$. Powierzchowne podejście do zagadnień religijnych, promowana przez media tolerancja i światopoglądowa otwartość sprzyjają współcześnie swoistemu „ekumenizmowi na siłę”, który pomija różnice, koncentrując się wyłącznie na podobieństwach.

Termin „meandry” użyty w tytule artykułu, jak przypominają różne słowniki, sugeruje m.in.: pewne subtelności, tajemnice, niejasności, zawiłości, bariery, bolączki, komplikacje, niedogodności, niedomagania, niepraktyczność, perturbacje, poplątanie, powikłania, problematyczność, przeszkody i trudności, uciążliwość, a nawet udrękę, utrapienie, zawadę, zmartwienie i bezdroża. W Słowniku języka polskiego także można odnaleźć określenie „meandry”, które oznacza skomplikowany i często trudny do zrozumienia bieg wydarzeń lub czyichś myśli. Wydaje się, że takie właśnie, zarówno od strony historycznej, jak i rozważań dotyczących współczesnego ekumenizmu, było i bywa podejście do tzw. „wychowania ekumenicznego".

W przedstawionym poniżej tekście zostanie ukazany ów meandryczny charakter wychowania religijnego, które rościłoby sobie prawo do ujednolicenia różnych oddziaływań wychowawczych poszczególnych wyznań chrześcijańskich, próbując zamknąć je czy swoiście ograniczyć do przymiotnika „ekumeniczny". Rozważania rozpoczną się od swoistej syntezy rozwoju ewangelickiej myśli pedagogiczno-religijnej, by następnie - mając na uwadze zarysowany kontekst - wskazać istotne kwestie związane z tzw. wychowaniem ekumenicznym.

${ }^{1}$ Por. R. Cha£UPNIAK, Konfesyjność nauczania religii. Zarys problematyki, „Paedagogia Christiana" $3(2000) \mathrm{nr} 2,32$. 


\section{1. „Ponad podzialami” - historyczne doświadczenia ewangelickie}

Silne zainteresowanie ekumenicznym wychowaniem religijnym można łączyć ze swoistym kryzysem religijnego wychowania, jaki ujawnił się już w początkach XIX w. W wielkiej dyskusji brał udział m.in. Friedrich Schleiermacher - protestancki teolog, filozof i pedagog (1768-1834), dla którego nauczanie religii $\mathrm{w}$ szkole stało się istotnym problemem. W licznych dysputach poszukiwano skutecznych i adekwatnych do zmieniających się sytuacji społeczno-religijnych nowych koncepcji szkolnego wychowania religijnego. W żywe dyskusje włączali się pedagodzy, teolodzy i politycy, którzy próbowali wskazać właściwy model szkolnego nauczania religii, który dokonywał się w swoistym napięciu między państwem i wspólnotami religijnymi, etyką i religią, życiem i wiarą ${ }^{2}$. Nowe kierunki powstawały głównie na gruncie ewangelickiej pedagogiki religijnej i przechodziły swoisty sprawdzian praktyczny w postaci ewangelickiej lekcji religii ${ }^{3}$.

$\mathrm{W}$ połowie $\mathrm{XX}$ w. $\mathrm{w}$ ramach ewangelickiej pedagogiki religijnej rozwinęły się kolejne modele nauczania religii. Ich rozpowszechnienie możliwe było dzięki licznym czasopismom i centrom pedagogiczno-teologicznym. Już wówczas mówiło się o lekcji religii zorientowanej problemowo, nastawionej na cele i sytuacje, o lekcji religii jako krytyce ideologii czy wprowadzeniu w socjalizację lub dydaktyce symboli ${ }^{4}$. Były to koncepcje alternatywne dla ewangelickiego pouczenia w wierze (evangelische Unterweisung), które w sytuacji wzrastającej sekularyzacji utraciło swą wcześniejszą popularność i skutecznośćs. Ewangelicki pedagog religijny, Wilhelm Sturm, scharakteryzował i ocenił różne koncepcje szkolnej lekcji religii ${ }^{6}$. Były to:

1. Koncepcje „wychowania ewangelickiego":

a. bezpośredniej dogmatycznej dedukcji (G. Bohne, A. Fankheuser);

b. zróżnicowanej dogmatycznej dedukcji (K. Frös, H. Kittels).

2. Koncepcje ,świeckiego wychowania” (O. Hammelsbeck, G. Otto).

3. Koncepcje uzasadniające kościelne zaangażowanie:

2 G. Lämmermann, Grundriss der Religionsdidaktik, Stuttgart 1991, 126 nn.

${ }^{3}$ D. Stoodt, Religionsunterricht in Deutschland, w: N. MetTe, F. Rickers (red.), Lexikon der Religionspädagogik, t. II, Neukirchen-Vluyn 2001, 1778. Por. R. ChaŁuPNiaK, Między katecheza a religioznawstwem. Nauczanie religii katolickiej w szkole publicznej w Niemczech w latach 1945 2000, Opole 2005, 158-160.

${ }^{4}$ D. Stoodt, Religionsunterricht in Deutschland, 1778.

${ }_{5}^{5}$ Por. M.U. Schmidt, Konzeptionen des Evangelischen Religionsunterrichts, w: I. Cosold, P. KLIEmann (red.), ,, Ach, Sie unterrichten Religion? “. Methoden, Tipps und Trends, Stuttgart 2003, 58-65; A. Schulte, I. Wiedenroth-Gabler, Theologie kompakt: Religionspädagogik, Stuttgart 2003, $54-75$.

${ }^{6}$ Por. W. STURM, Religionsunterricht: gestern - heute - morgen. Der Erziehungsauftrag der Kirche und der Religionsunterricht an öffentlichen Schulen, Stuttgart 1971, 7-14. 
a. lekcja religii jako przepowiadanie i wezwania do decyzji (G. Bohne);

b. lekcja religii jako „Kościół w szkole” (M. Rang);

c. misyjna lekcja religii (O. Hammelsbeck);

d. lekcja religii jako przepowiadanie i wychowanie (K. Frös, S. Wolf);

e. lekcja religii jako ewangeliczne nauczanie (H. Kittel).

4. Koncepcje akcentujące szkolne uzasadnienie:

a. lekcja religii jako hermeneutyka (M. Stallmann, G. Otto);

b. lekcja religii zorientowania humanistycznie (G. Otto, H. Stock);

c. lekcja religii jako religioznawstwo;

d. lekcja religii jako krytyka religii i społeczeństwa.

$\mathrm{W}$ ewangelickiej pedagogice od połowy XX w. intensywnie poszukiwano takiego modelu lekcji religii, który z jednej strony zastąpiłby nie przez wszystkich akceptowany kierunek ewangelizacyjny, z drugiej - posiadałby solidne uzasadnienie pedagogiczno-szkolne. W ten sposób dały o sobie znać wyraźnie skrajne stanowiska: dla jednych lekcja religii była wychowaniem wiary, dla innych - wyłącznie religioznawstwem. W ewangelickiej pedagogice religijnej mówiono coraz częściej o odejściu od konfesyjnego nauczania religii, o przejściu od biblijnej do niebiblijnej lekcji religii, o konieczności nie teologicznego, ale pedagogicznego uzasadnienia tych zajęć ${ }^{7}$.

W Nowym stowniku terminów religijno-pedagogicznych z 2002 r. inny ewangelicki pedagog, P. Biehl, wyróżnił następujące koncepcje szkolnego nauczania religii :

1. Typ kerygmatyczny:

a. kierunek materialno-kerygmatyczny - katolicki (1936-1967);

b. lekcja religii jako przepowiadanie - ewangelicki (1929-1960).

2. Typ hermeneutyczny (bez rozróżnienia na wyznanie):

a. lekcja hermeneutyczna (od 1958 r.);

b. lekcja skoncentrowana na problemach (od 1968 r.);

c. korelacja wiary i życia (od 1972 r.);

d. dydaktyka symbolu (od 1980 r.);

e. dydaktyka elementaryzacji (od 1982 r., umocniona od 1995 r.);

f. hermeneutyka doświadczenia (od 1997 r.).

Powyższe wyliczenie uprawnia do stwierdzenia, że zasadniczy przełom koncepcyjny w ewangelickiej lekcji religii dokonał się w latach 60. i $70 \mathrm{XX}$ w. Ten czas charakteryzują liczne, kontrowersyjne dyskusje oraz pojawiające się nowe

7 Por. H. Grosch, Religionspädagogik am Scheideweg. Der Religionsunterricht zwischen Humanwissenschaften und Theologie, Gütersloh 1974, 15-28.

${ }^{8}$ Por. P. Biehl, Religionsdidaktische Konzeptionen, w: G. Bitter, R. Englert, G. Miller, K.E. NiPKOw (red.), Neues Handbuch religionspädagogischer Grundbegriffe, München 2002, 440446. 
koncepcje, podkreślające poszczególne aspekty w religijnym nauczaniu, stawiające wysokie wymagania wobec uczniów i nauczycieli. Nieustannie rozprawiano o kwestiach teoretycznych czy polityczno-eklezjalnych w obliczu instytucjonalnych przemian, reform szkolnego systemu, wzrastającej konkurencji ze strony lekcji o społecznych relacjach (Sozialkunde) i etyki, naukowych wymagań wobec kształcenia nauczycieli, wobec wystąpień z Kościoła, imigracji, pozainstytucjonalnego fenomenu religijnego. Lekcja religii stała się miejscem, gdzie nie tyle przekazywano określoną wiedzę i umiejętności, co raczej coraz częściej prowadzono różne dyskusje na temat religii, Kościoła, świata i człowieka9.

Ważny wpływ na współczesne kierunki szkolnego nauczania religii, nie tylko w ich ewangelickim wydaniu, posiadała teologia systematyczna Paula Tillicha (1886-1965) z jego definicją religijności nie jako „wiary w istnienie Boga”, lecz jako „ukierunkowanie na to, co konieczne” (Richtung auf das Unbedingte), „stan wzruszenia” (Zustand des Ergriffenseins), „odpowiedź na pytanie o sens życia” (die Antwort auf die Frage nach dem Sinn unseres Lebens), „to, co nadaje sens życiu” (das, was dem Leben seinen Sinn gibt), „wymiar głębi w całości ludzkiego ducha" (die Dimension der Tiefe in der Totalität des menschlichen Geistes) czy wreszcie najkrócej - „to, co konieczne” (das Unbedingte) ${ }^{10}$. Z biegiem czasu pedagodzy, a właściwie już bardziej dydaktycy religii, z definicji religii uczynili punkt wyjścia swoich teoretycznych opracowań ${ }^{11}$. W takim podejściu coraz mniej chodziło o wiarę, bardziej natomiast o coraz szerzej rozumianą religię ${ }^{12}$; lekcja religii coraz bardziej przechylała się w stronę religioznawstwa.

9 D. Stoodt, Religionsunterricht in Deutschland, 1778. Por. także: A. Feige, Kirchenmitgliedschaft in der BRD, Gütersloh 1990, 279-293.

${ }^{10}$ H. Fox, Schule und Religionsunterricht, w: H.G. Ziebertz, W. Simon (red.), Bilanz der Religionspädagogik, Düsseldorf 1995, 399-402; por. także: G. BAUDLER, Einerlei oder zweierlei Religionsbegriff-Die Frage sachlich verstanden, KB 100 (1975), 694-701; E. FEIL, Einerlei oder zweierlei Religionsbegriff - oder: „Die Kunst, es nicht gewesen zu sein“?, KB 100 (1975), 692-694; H. GöPFERT, Pauls Tillichs Religionsbegriff und die Folgen für die Didaktik des Religionsunterrichts. Ein Diskussionsbeitrag zu Überlegungen von Siegfried Vierzig und Hubertus Halbfas, „rhs. Religionsunterricht an höheren Schulen" 16 (1973), 14-24; TENŻE, Religionsunterricht und weltanschauliche Pluralität. Problem und Lösungsvorschlag für den Primarbereich, Stuttgart - München 1974, 132-144; H. RöER, Tillichs Religionsbegriff im Zwielicht, KB 101 (1976), 341-346, TENŻE, Christentum - Religion unter Religionen?, „rhs. Religionsunterricht an höheren Schulen” 21 (1978), 129-132. Dokładna analiza wpływu pojęcia religii P. Tillicha na pedagogikę religijną por.: W. Simon, Inhaltsstrukturen des Religionsunterrichts. Eine Untersuchung zum Problem der Inhalte religiösen Lehrens und Lernens, Zürich 1983, 316-330. Na kanwie takich poglądów rozwija się tzw. świecka pedagogika religijna - por. R. Dross, Profane Religionspädagogik, w: N. METtE, F. RICKERS (red.), Lexikon der Religionspädagogik, t. II, 1565-1568.

${ }^{11}$ H.G. ZiEBERTz, Warum die religiöse Dimension der Wirklichkeit erschließen?, w: G. HiLGER, S. Leimgruber, H.G. Ziebertz, Religionsdidaktik. Ein Leitfaden für Studium, Ausbildung und Beruf, München 2001, 107-122. Por. R. CHAŁUPNIAK, Między katechezq a religioznawstwem, 161.

${ }^{12}$ Do terminologii P. Tillicha odwoływali się m.in. tacy autorzy, jak: Siegfried Vierzig i Werner Esser. Różnica polegała na znaczeniu, jakie poszczególni autorzy przypisywali określonym instytucjonalnie formom religii dla szkolnego nauczania religii. Por. G. BAUDLER, Religiöse Erziehung heute. Grundelemente einer Didaktik religiösen Lernens in der weltanschauliche pluralen 
Promowany w połowie XX w. model „szkolnej lekcji religii jako wychowania wiary" (Religionsunterricht als Glaubensunterweisung) poddawany był silnej krytyce. Pedagodzy ewangeliccy wskazywali na inne możliwe uzasadnienia szkolnej lekcji religii. M. Stallman (1903-1980) chciał wyprowadzić argumentację za lekcją religii wyłącznie z perspektywy szkoły. Jego zdaniem, lekcja hermeneutyczna dawała uczniom „odpowiedź na pytanie o możliwości ludzkiej egzystencji” ${ }^{13}$, dostosowując się do rzeczywistości szkolnej nie w sensie przepowiadania czy wychowania wiary (Glaubensverkündigung oder -einübung), lecz jako interpretacja (Auslegung) określonej, własnej tematyki. Celem takich zajęć nie miało być „wprowadzenie w wiarę”, lecz ,zrozumienie wiary i siebie samego w świetle wymagań płynących z wiary"14. O podobnej ,totalnej integracji lekcji religii ze szkołą" wspominał inny pedagog, G. Otto ${ }^{15}$. W hermeneutycznej lekcji religii istotna była interpretacja i zrozumienie ${ }^{16}$. Coraz częściej podnoszono postulaty odkościelnienia tych zajęć ${ }^{17}$. Pojawiały się niezrozumiałe teologicznie tendencje, by „prawdziwość wiary” (die Wahrheit des Glaubens) zastępować przez „słuszność poznania” (die Richtigkeit der Erkenntnis ${ }^{18}$. Krytyka dotychczasowych lekcji religii objęła także treści, które choć głęboko biblijne - były dalekie od właściwych problemów tak całego społeczeństwa, jak i poszczególnych uczniów, nie uwzględniały w wystarczający sposób czynników psychologicznych, socjologicznych i pedagogicznych.

Przełomowy w historii rok 1968 i związane z nim przemiany społeczne spowodowały silne poruszenie także na gruncie szkolnego nauczania religii. Po raz pierwszy doszło do tak ostrych wystąpień wobec tych lekcji religii: wielu rodziców wypisało swoje dzieci z tych zajęć, spora liczba nauczycieli religii zrezygnowała z prowadzenia tego przedmiotu. Podważano wszelkie autorytety, powątpiewano w sens istnienia różnych instytucji, także wspólnot religijnych, obawiając się wszelkiego rodzaju autorytatywnego nauczania, religijnej propagandy, manipulacji i indoktrynacji ${ }^{19}$. Według przytaczanych przez ewangelickie-

Gesellschaft, Paderborn 1979, 40-46; H. SchILLING, Religion in der Schule. Eine Einführung in die Problematik des Religionsunterrichts an der staatlichen Schule, München 1972, 60-67.

${ }_{13}$ M. Stallmann, Christentum und Schule, Stuttgart 1958, 168; por. W. STURM, Religionsunterricht: gestern - heute - morgen, 7-14.

${ }^{14}$ Por. W. ReEs, Der Religionsunterricht und katechetische Unterweisung in der kirchlichen und staatlichen Rechtsordnung, Regensburg 1986, 198.

${ }^{15}$ G. Отто, Schule - Religionsunterricht - Kirche. Stellung und Aufgabe des Religionsunterrichts in Volksschule, Gymnasium und Berufsschule, Göttingen 19683 178.

16 Por. W. Langer, Kerygma und Katechese, München 1966, 56.

${ }^{17}$ K. Lang, Veränderte Zielstellung des Religionsunterrichts. Von der Verkündigung zur Auslegung, ChPB 82 (1969), 9-12.

${ }_{18}$ Por. G. Gnand, Konzeptionen des Katholischen Religionsunterrichts, w: I. Cosold, P. KLIEMANN (red.), ,,Ach, Sie unterrichten Religion?", 67.

19 Por. G. BAudLer, Der Religionsunterricht an der deutschen Schule. Eine erste Bilanz, München 1971, 30; A. EXELER, Religionsunterricht im Spannungsfeld zwischen Kirche und Schule, w: W.G. EsSER (red.), Zum Religionsunterricht morgen. Perspektiven künftiger Religionspädagogik, 
go pedagoga, A. von Campenhausena, opinii różnych polityków, prawników i dydaktyków, lekcja religii powinna szybko zniknąć z publicznych szkół ${ }^{20}$. Społeczny i polityczny klimat „kulturalnej rewolucji” końca lat 60. XX w. zmuszał do gruntownego przemyślenia i przepracowania legitymacji i kształtu szkolnego nauczania religii.

$\mathrm{Na}$ fali krytyki opracowano model nauczania religii jako religioznawstwa (Religionskunde, Sachkunde Religion) ${ }^{21}$, którego zadaniem miało być przekazanie wiedzy dotyczącej różnych religii bez jakichkolwiek uprzedzeń czy wcześniejszych przesłanek (w tym biblijnych i teologicznych). Treścią miał być fenomen religijności w historii i teraźniejszości. Uzasadnienie takich zajęć na terenie szkoły publicznej wiązałoby się z koniecznością poznania różnych religii, które przecież obecne są realnie w życiu społeczeństwa, bez których nie można całościowo i adekwatnie poznać i zrozumieć otaczającej rzeczywistości. Charakterystyczne dla tego kierunku było położenie nacisku na informację, na wiedzę, która opierałaby się na neutralnym stanowisku i byłaby ważna tak dla ucznia wierzącego, jak i niewierzącego ${ }^{22}$. Każdy mógłby z takich zajęć zabrać dla własnego przekonania to, co chciałby. Z góry wykluczone były jakiekolwiek formy zachęcania czy argumentowania za określonym stanowiskiem. Ten kierunek ujmował lekcję religii jako kulturowo-hermeneutyczną wymianę informacji. Przy takim określeniu zajęcia te były postrzegane jak wszystkie inne pozostałe przedmioty szkolne. Wymaganie, aby przekaz treści odbywał się bez jakichkolwiek elementów perswazyjnych, wiązał się jednak z koniecznością odkonfesyjnienia tych zajęć i pozbawienia wspólnot religijnych wszelkich wpływów na ich kształt. Zyskiwała natomiast pozycja nauczyciela, który stawał się w ten sposób niezależnym od czynników kościelnych ekspertem

t. I, München 1970, 326-327; N. Havers, Der Religionsunterricht. Analyse eines unbeliebten Faches, München 1972, 155; R. MENsing, Funktion des Religionsunterrichts, ,rhs. Religionsunterricht an höheren Schulen" 12 (1969), 162-164; H. MynAReK, Manipuliert die Religion den Menschen?, ChPB 83 (1970), 299-306; U. SchMÄLzE, Miteinander Leben und Glauben lernen. Grundlagen der Evangelisation in der Schule, w: W. IsENBERG (red.), Nicht nur Unterricht-pastorales Engagement in der Schule. Aspekte der Schulseelsorge, Bensberg 1992, 24-27; O. WANKE, Glaubensgehorsam und menschliche Freiheit, KB 99 (1974) 601-613; R. CHAŁUPNIAK, Między katecheza a religioznawstwem, 166-168.

${ }^{20}$ A. von CAmpenhausen, Der Religionsunterricht im weltanschaulich neutralen Staat, w: W.G. Esser (red.), Zum Religionsunterricht morgen, 82.

${ }^{21}$ Por. W. Bartholomäus, Einführung in die Religionspädagogik, München 1982, 198-201. Postulaty „neutralnej wyznaniowo” (bekenntnisneutral), „naukowo-obiektywnej” (wissenschaftlich-objektiv), jedynie informującej (informierend) i odkościelnionej lekcji religii nie były nowe por. P. Natorp, Leitsätze zum Religions-Unterricht, w: W. ReIN (red.), Stimmen zur Reform des Religions-Unterrichts, t. II, Langensalza 1906, 5-6.

${ }^{22}$ U podstaw tego kierunku leżały m.in. poglądy Th. Wilhelma, który postulował, by w szkole wszystko było „naukowe” i ,w sposób naukowy - krytycznie i racjonalnie ujmowane i oceniane”Тн. Wilhelm, Theorie der Schule. Haupschule und Gymnasium im Zeitalter der Wissenschaften, Stuttgart 1967, 295. Na czas lekcji należy „porzucić wiarę” i przyjąć postawę sceptyczną (tamże, $307)$. 
i fachowcem w dziedzinie religii. Bezpośrednim odniesieniem dla przekazywanych treści nie była już teologia, lecz religiologia, fenomenologa i historia religii. Treść wymagała radykalnego przepracowania i włączenia w zajęcia także innych znaczących religii ${ }^{23}$. W religioznawczych zajęciach takie tematy, jak: „religia”, „wiara”, „Kościół”, „religie świata”, nie zawsze były ukazywane pozytywnie. Często odwoływano się do różnych historycznych wydarzeń, by w ich świetle ocenić konkretne doświadczenia religijne. W zależności od jej oddziaływania i znaczenia dla społeczeństwa dochodziło do krytyki określonej religii. Poddawano rozważaniom podstawowe doświadczenia religijne, ukazując, że mają być one wciąż na nowo odkrywane i przepracowywane ${ }^{24}$.

J. Kahl twierdził, iż w imię ,wolności religijnej” lekcja religii winna stać się „naukowym religioznawstwem” (wissenschaftliche Religionskunde), które wprowadza we wszystkie religie, jednocześnie poddając je krytyce. Taka obligatoryjna dla wszystkich forma edukacji religijnej uzdalniałaby uczniów (niezależnie od przekonań ich rodziców) do własnego wyboru religii, do której by się przekonali ${ }^{25}$. O. Thimme z czysto praktycznych względów uzasadniał, że takie przeorganizowanie zajęć z konfesyjnej lekcji religii na przedmiot „religia i światopogląd" (czyli ich odkonfesyjnienie) wiązałoby je mocniej ze szkołą ${ }^{26}$. Takie multikonfesyjne zajęcia powinny dotyczyć różnych wyznań i religii, a także pomóc $\mathrm{w}$ podjęciu własnej decyzji wobec przekazywanych treści ${ }^{27}$. Zasadniczym odniesieniem dla opracowywania treści byłyby nauki religiologiczne. K.E. Nipkow, ewangelicki pedagog, postulował, by w religioznawczej koncepcji lekcji religii pojawiały się elementy różnych religii ${ }^{28}$. Samo nauczanie religii powinno być podporządkowane ogólnemu procesowi dydaktycznemu, zadaniom i metodom szkoły, a decyzja wiary miała pozostać sprawą prywatną ${ }^{29}$. Sugerowano także, mimo konstytucyjnych zabezpieczeń konfesyjnych lekcji religii, by w szkole publicznej, która jest szkołą dla wszystkich (Schule für alle), prowadzone było również nauczanie religii obligujące do tych zajęć wszystkich uczniów (Religi-

${ }^{23}$ Por. G. GNand, Konzeptionen des Katholischen Religionsunterrichts, 68.

${ }^{24}$ Por. H. Fox, Kompendium Didaktik Katholische Religion, München 1986, 65-66.

${ }^{25}$ Por. J. Kahl, Das Elend des Christentums oder Plädoyer für eine Humanität ohne Gott, Reinbeck bei Hamburg 1968, 128; H. SchiLling, Religion in der Schule. Eine Einführung in die Problematik des Religionsunterrichts an der staatlichen Schule, München 1972, 39.

${ }^{26}$ O. Thimme, Vom Religionsunterricht zur Religionskunde. Zur Theorie und Praxis einer Entwicklung, w: K. WegEnAST (red.), Religionsunterricht-wohin? Neue Stimmen zum Religionsunterricht an öffentlichen Schulen, Gütersloh 1971, 250.

27 Por. H. HalBfas, Aufklärung und Widerstand. Beiträge zur Reform des Religionsunterrichts und der Kirche, Stuttgart - Düsseldorf 1971, 56; TENŻE, Katechese als Innovation kirchlicher Reformprozesse, w: G. BAUdler (red.), Schulischer Religionsunterricht und kirchliche Katechese, Düsseldorf 1973, 57-79.

${ }^{28}$ Por. K.E. NIPKOw, Die Weltreligionen im Religionsunterricht der Oberstufe, „Evangelischer Erzieher" 13 (1961), 150-162; Ch. GRETHLEIN, Religionspädagogik, Berlin - New York 1998, 171.

${ }^{29}$ C. Rogowski, Koncepcje katechetyczne po Soborze Watykańskim II, Lublin 1997, 31-35. 
onsunterricht für alle) ${ }^{30}$. W przeświadczeniu sporej grupy pedagogów religijnych takie zajęcia, podobnie jak działo się to w szkołach angielskich i szwedzkich, umożliwiłyby wprowadzenie każdego ucznia w zagadnienia religijne na zasadzie religioznawstwa niezależnie od jego osobistych przekonań. H. Göpfert wysunął żądania wobec lekcji religii: nie powinny to być zajęcia dotyczącej tylko jednej religii; jako lekcja „o religiach” nie powinna być religijnym wychowaniem; nie może przekazywać religijnych doświadczeń; powinna koncentrować się na wielkich religiach świata, nie na religiach antycznych czy początkach religii; należy odnosić zagadnienia religijne do egzystencjalnych problemów; trzeba rozważać źródła religii, a nie ich subiektywne odczytanie ${ }^{31}$.

Kierunek religioznawczy w pedagogice religijnej pozostawił po sobie dyskusyjną kwestię traktowania lekcji religii wyłącznie jako informacji (Religionsunterricht als Information), która wiązała się z uświadomieniem lub zrozumieniem przekazywanych treści, jednakże bez wywierania jakiegokolwiek wpływu, zachęcania do ich przyjęcia czy „werbowania”. Takie ustawienie dawało uczniom możliwość zdystansowania się do treści i niezależnego kształtowania własnych przekonań. W ten sposób przeciwstawiono sztucznie dwa pojęcia, tworząc alternatywę: albo informacja, albo przepowiadanie (Information oder Verkündigung) $)^{32}$. Przez „,przepowiadanie” rozumiano kerygmatyczne głoszenie

${ }^{30}$ Por. G. BAUDLER, Atheisten im Religionsunterricht? Biblische Überlegungen zum Problem eines obligatorischen Religionsunterrichtes in der pluralistischen Gesellschaft, KB 92 (1967), 661-667; U. BECKER, Religionsunterricht an der öffentlichen Schule, w: H. NOORMANN, U. BECKER, B. Trocholepczy (red.), Okumenisches Arbeitsbuch Religionspädagogik, Stuttgart 2004², 101-102; R. Burrichter, Eine Kirche für alle Religionen. Zu Niki de Saint Phalles Skulptur ,,Le temple idéal “, KB 118 (1993), 493-496; R. ENGLerT, Theorie und Praxis des Religionsunterrichts an Grundschulen, w: R. Göllner, B. Trocholepczy (red.), Religion in der Schule? Projekte-Programme - Perspektiven, Freiburg 1995, 138-140; W.G. Esser, Warum alle Kinder und Jugendlichen Religionsunterricht brauchen, w: J. Lотт (red.), Religion - warum und wozu in der Schule?, Weinheim 1992, 253-267; W. FleCKensteIn, Religionsunterricht für einen ",heiligen Rest" oder „für alle ". Die diakonische Funktion des Religionsunterrichts als Zukunftsperspektive, „Religionspädagogische Beiträge" (1989) nr 24, 26-44; U. Hemel, Religionspädagogik im Kontext von Theologie und Kirche, Düsseldorf 1986, 115-116; H.E. Kappel, C. Strohbecke, Obligatorische Religion-Kunde, w: J. Lотт (red.), Religion - warum und wozu in der Schule?, 407-420; N. Metтe, Religionspädagogik, Düsseldorf 1994, 213; G. Отто, Allgemeiner Religionsunterricht-Religionsunterricht für alle. Sieben Thesen mit Erläuterungen, w: J. Lотт (red.), Religion - warum und wozu in der Schule?, 359-374; R. PADBERG, Entkonfessionalisierung des Religionsutrerrichts. Zur Frage des Religionsunterrichts an öffentlichen Schulen, Paderborn 1973, 31-38; H. Schilling, Religion in der Schule, 35; J.H. SCHNEIDER, Schule - Kirche - Seelsorge. Schulbezogene Arbeit der Kirchen im Übergang, Düsseldorf 1976, 102-116; U. SIEG, „,Religionsunterricht für alle“. Interreligiöses Lernen von Anfang an!, w: R. EHMANN I IN. (red.), Religionsunterricht der Zukunft. Aspekte eines notwendigen Wandels, Freiburg 1998, 132-141; G. STACHEL, Lernziele und Religionsunterricht, KB 95 (1970), 347.

${ }^{31}$ H. GÖPFERT, Religionsunterricht und weltanschauliche Pluralität. Problem und Lösungsvorschlag für den Primarbereich, Stuttgart - München 1974, 109-110.

${ }_{32}$ W. REES, Der Religionsunterricht und katechetische Unterweisung in der kirchlichen und staatlichen Rechtsordnung, 201-202. Por. W. BARTHOLOMÄUs, Evangelium als Information. Elemente einer theologischen Komunikationstheorie am Beispiel der Osterbotschaft, Zürich - Einsiedeln - Köln 1972; H. JASCHKE, Religionsunterricht in der Schule. Besinnung eines persönlich betroffenen Lehrers, KB 94 (1969), 529-534; E.J. KorHERR, Hilfen zum Gespräch über den Religionsunterricht, ChPB 90 (1977), 253-254. 
Ewangelii, które za cel miało dojrzałą wiarę i zaangażowanie w życie Kościoła. Powątpiewano, czy takie cele mogą być zrealizowane w ramach szkolnej lekcji religii. Jako alternatywę proponowano przekaz obiektywnych wiadomości (die Vermittlung eines objektiven Wissens $)^{33}$ oraz rezygnację z konfesyjnego kształtu na rzecz zajęć religioznawczych ${ }^{34}$. To symptomatyczne przejście od katechezy do religioznawstwa, od przepowiadania do informowania, od wychowania do nauczania, stało się dla wielu pedagogów religijnych pretekstem do modyfikacji wychowania ekumenicznego.

\section{Od „katechezy ekumenicznej” do „ekumenicznego wymiaru katechezy”}

W powyższy kontekst sporów dotyczących różnych modeli szkolnego nauczania religii wpisuje się szersza kwestia tzw. „wychowania ekumenicznego". Warto pamiętać, że dyskusje prowadzone zarówno na płaszczyźnie teorii pedagogicznej, jak i w obszarze codziennej praktyki mocno wpływają na indywidualne przekonania, a także na kształtujące się nieustannie koncepcje wychowawcze, także dotyczące tak delikatnej sfery, jaką jest osobiste odniesienie do Boga.

Wychowanie religijne zakłada coś więcej niż tylko sam przekaz określonych wiadomości dotyczących danej religii czy wyznania (nauczanie religijne). Wychowanie jest odniesieniem zarówno do płaszczyzny wiedzy, jak i umiejętności (dydaktyka), a także do bardzo szeroko ujętej płaszczyzny osobistych przekonań i pragnień. Obejmuje - jak dawniej określano - sferę intelektualną („wiem, rozumem, potrafię”), wolitywną („chcę”) i działaniową („realizuję, wypełniam we własnym życiu"). Wychowanie religijne może być utożsamiane z katechezą (,wychowaniem w wierze”), o ile dotyczy wspomnianych płaszczyzn oraz - jest to warunek podstawowy - odnosi się do wiary zarówno w jej aspekcie obiektywnym (tzw. fides quae), jak i subiektywnym (fides qua). Katecheza jest zawsze

${ }^{33}$ Por. J. MüLlER, Religionsunterricht - ein Schulfach. Zur Praxis der Unterrichtsgestaltung, Wien - Freiburg - Basel 1977, 12. Sprowadzeniu lekcji religii wyłącznie do przekazu kognitywnego sprzeciwiało się wielu pedagogów. Wciąż na nowo podnoszono postulat większego zaangażowania emocjonalnego uczniów - por. G. REILLY, Sinnerschließung und Emotionen. Ein Beitrag zur Frage der emotionalen Dimension des Religionsunterrichts, „Religionspädagogische Beiträge" (1984) nr 13, 156-171; R. Sistermann, Zu einer Theorie der Gefühle als Grundlage emotionalen Lernens im Religionsunterricht, „Religionspädagogische Beiträge” (1992) nr 30, 58-79; H.A. ZwERGEL, Affekt-Bildung im Religionsunterricht als Beitrag zur religiösen Identitätsfindung, KB 99 (1974), 546-553; TENŻE, Zur emotionalen Verankerung religiöser Lernprozesse, „Religionspädagogische Beiträge" (1994) nr 33, 40-60.

34 B. JENDORFF, Vom konfessionellen Religionsunterricht zu Unterricht über Religion, „rhs. Religionsunterricht an höheren Schulen” 16 (1973), 225-239; W. CREMER, Schule und Religion. Überlegungen eines Religionswissenschaftlers, w: K. WEGENAST (red.), Religionsunterricht - wohin?, 225-240. Por. R. ChalupNiaK, Między katechezq a religioznawstwem, 170-171. 
wprowadzaniem w wiarę określonej wspólnoty religijnej i nie może być jedynie zawężona do przekazu treści wiary (,w kogo/w co się wierzy?”).

Jeśli potraktujemy słowo „oksymoron” w jego leksykalnym sensie, jako metaforyczne zestawienie wyrazów o przeciwstawnym, wykluczającym się znaczeniu, to dobrze oddawałoby treść terminu „katecheza ekumeniczna”. Takiej katechezy nie może być z samego założenia - poszczególne chrześcijańskie denominacje różnią się istotowo od siebie w zakresie wyznawanej, przeżywanej i celebrowanej wiary, stąd nie jest możliwe prowadzenie katechezy (,wychowania w wierze") dla uczniów różnych wyznań. Łączenie katechezy bezpośrednio z przymiotnikiem „ekumeniczny” tworzy wiele zawiłości, owych tytułowych „meandrów”.

Przywołana w pierwszej części tekstu historia dyskusji na temat szkolnego nauczania religii ewangelickiej wskazuje na złożoność problemu. Wychowanie religijne, jeśli nie jest zredukowane wyłącznie do nauczania (przekazu treści), zawiera elementy przeżyciowe, wolitywne i działaniowe. Oczywiście, może być radykalnie czy stopniowo pozbawiane tych elementów i - jak wskazują to kolejne modele szkolnych lekcji religii - sprowadzone do suchej informacji na temat jednej czy wielu religii. W Niemczech nauczanie religii w szkole, gwarantowane konstytucyjnie, domaga się rozróżnienia konfesyjnego ${ }^{35}$. Okazuje się jednak, że coraz częściej pojawiają się próby: albo zmiany formuły nauczania konfesyjnego, albo nawet jej zniesienia. W niektórych przypadkach takie działanie argumentowane jest postawą ekumeniczną oraz koniecznością większego otwarcia na inne wyznania i religie obecne w społeczeństwie. W tym kierunku poszły również uzasadnienia - jak wcześniej wspomniano - obecności nauczania religii w takich krajach, jak Anglia czy Szwecja, gdzie w szkole prowadzone są zajęcia o charakterze religioznawczym.

Osoby odpowiedzialne za przekaz wiary przyszłym pokoleniom muszą wciąż na nowo konfrontować swe przekonania i działania z różnymi wyzwaniami. M.in. pojawia się istotne pytanie: Jak powinno współcześnie funkcjonować wychowanie ekumeniczne? Wydaje się, że ciekawym, całościowym i bardzo praktycznym rozwiązaniem jest pomysł, który przedstawił Jerzy Kostorz ${ }^{36}$. Autor ten wyraźnie

35 Por. R. ChaŁupniak, Konfesyjność nauczania religii. Zarys problematyki, „Paedagogia Christiana” 3 (2000) nr 2, 38-39; TENŻE, Między katecheza a religioznawstwem, 356-361.

36 J. Kostorz, Ekumeniczny wymiar posoborowej katechezy w Polsce, Opole 2007. Por. także publikacje innych katolickich teologów, np.: J. BAGROwICZ, Edukacja religijna w stużbie wychowania młodzieży do postawy dialogu i tolerancji, w: K. Konecki, Z. PaWlaK, K. Rulka (red.), Teologia. Ekumenizm. Kultura, Włocławek 2006, 243-254; J. ChARYTAŃski, Wymiar ekumeniczny, w: M. Majewski (red.), Podstawowe wymiary katechezy, Kraków 1991, 129-143; J. Chrzanowski, O wychowanie ekumeniczne, Kat 28 (1984) nr 2, 77-78; W. Hanc, Ekumeniczny wymiar całej teologii, w: W. Hryniewicz, J.S. GajeK, S.J. Koza (red.), Ku chrześcijaństwu jutra. Wprowadzenie do ekumenizmu, Lublin 1997, 581-586; TENŻE, Ekumeniczny wymiar katechezy, „Studia Oecumenica" 4 (2004), 183-207; W. HŁadowsKI, Wychowanie do ekumenizmu, w: W. HRYNIEWICZ, J.S. GA- 
wskazuje na konieczność włączenia w proces wychowania zagadnień ekumenicznych, więcej - domaga się, by przenikać elementami ekumenicznymi kolejne etapy religijnego kształcenia. J. Kostorz pisze o „ekumenicznym wymiarze katechezy", pod którym rozumie rozwijanie postawy dialogu, tolerancji i poszanowania dla inaczej wierzących ${ }^{37}$. Dokumenty katechetyczne, przeanalizowane przez niego, nie tylko akcentują potrzebę realizowania w praktyce katechetycznej ekumenicznego wymiaru, lecz również podają wytyczne dotyczące jego wprowadzania. Katecheza ma wymiar ekumeniczny, jeśli prowadzi do szczerego nawrócenia osób i wspólnot według Ewangelii, kiedy daje solidną i poprawną znajomość różnych wyznań chrześcijańskich, przezwyciężając w ten sposób ignorancję oraz uprzedzenia. Katecheza taka powinna kształtować postawy szacunku i miłości względem innych, pokory i szczerości, zdolności słuchania i gotowości uczenia się oraz zgody na wzbogacanie siebie przez kontakt z innymi, przez różne formy dialogu i współpracy (modlitwa, nauka, akcje społeczne, wspólne zaangażowanie na rzecz sprawiedliwości i pokoju itp. $)^{38}$.

Zdaniem W. Hanca - z perspektywy katolickiej - katecheza, chcąc realizować ekumeniczny wymiar, powinna:

1. Uświadomić, iż winą za grzech rozdarcia obciążeni są wszyscy chrześcijanie bez wyjątku i bez podziału na ,inni” czy „oni”.

2. Uczynić z modlitwy arcykapłańskiej Chrystusa najbardziej wymowny środek do chrześcijańskiej jedności (ekumenizm dydaktyczny).

3. Prezentować zagadnienia chrystologiczne i pneumatologiczne, przy omawianiu tajemnicy Boga Trójjedynego, jako wspólne dziedzictwo, będące podstawą jedności wierzących w Chrystusa oraz jedności religijnej i ogólnoludzkiej na bazie chrześcijańskiego humanizmu.

4. Przy omawianiu wspólnej drogi chrześcijan ku zbawieniu uwypuklać fakt, iż więcej nas łączy niż dzieli.

5. Wskazywać na chrzest i Eucharystię, a także na inne sakramenty inicjacji chrześcijańskiej, jako na wyraźne znaki jedności.

JEK, S.J. KozA (red.), Ku chrześcijaństwu jutra, 723-730; P. JASKÓŁA, Ekumenizm w katechezie, w: R. Chalupniak, J. Kochel, J. Kostorz, W. Spyra (red.), Wokół katechezy posoborowej, Opole 2004, 73-76; G. Kusz, Ekumeniczna orientacja duszpasterstwa, w: W. HRYNIEWICZ, J.S. GAJEK, S.J. KozA (red.), Ku chrześcijaństwu jutra, 783-791; S. ŁabeNDowicz, Katecheza-wymiar ekumeniczny, w: C. Rogowski (red.), Leksykon pedagogiki religii. Podstawy - koncepcje - perspektywy, Warszawa 2007, 272-274; A. Nossol, Znaczenie ekumenizmu dla wychowania w sytuacji pluralizmu światopogladowego i religijnego, „Paedagogia Christiana” 8 (2001) nr 2, 29-34; W. NowaK, Ekumenizm, ekumeniczne nauczanie, w: C. RoGOWSKI (red.), Leksykon pedagogiki religii, 153-157; C. RoGowSKI, Wychowanie ekumeniczne, w: TENŻE (red.), Leksykon pedagogiki religii, 859-861. Na temat ekumenicznego wymiaru wychowania - zob. także: PAPIESKa RADA DS. JEDNośCI ChrZEŚCIJAN, Ekumeniczny wymiar formacji pastoralnej, Opole 1998.

${ }^{37}$ Por. J. Kostorz, Ekumeniczny wymiar, 19.

38 Por. TENŻE, Ekumeniczny wymiar, 79-80. 
6. Więcej czasu poświęcać innym wyznaniom, szczególnie w sytuacji, kiedy w szkole są uczniowie innych wyznań chrześcijańskich. Należy czynić to na gruncie obiektywizmu i życzliwości.

7. Odważnie przedstawiać główne prawdy wiary na różnych poziomach nauczania, zestawiając je z nauką innych chrześcijan.

8. Podkreślać to, co łączy, lecz nie przemilczać tego, co dzieli, jednak tak, aby katecheza nie rodziła antagonizmów i uprzedzeń.

9. Unikać stawiania na tej samej płaszczyźnie wszystkich Wspólnot i Kościołów.

10. Uwzględniać ewidentne owoce dialogów.

11. Kształtować autentyczną postawę ekumeniczną, co winno być owocem właściwej formacji ekumenicznej i ekumenicznego wymiaru katechezy ${ }^{39}$.

We właściwie rozumianym wychowaniu ekumenicznym istotne jest - jak przypominał Jan Paweł II w adhortacji Catechesi tradendae - dobra znajomość własnego Kościoła, a następnie poprawność demonstrowania innych wyznań (por. CT 32-33). Zdaniem papieża, katecheza o wymiarze ekumenicznym powinna przygotowywać dzieci, młodzież i dorosłych katolików do życia w kontakcie z niekatolikami, przy zachowaniu własnej tożsamości katolickiej i w poszanowaniu wiary innych. Autorzy Dyrektorium ogólnego o katechizacji z 1997 r. łączą tematykę ekumenicznego ukierunkowania katechezy z ewangelizacją i podkreślają, że taka katecheza powinna uczyć wprowadzania Ewangelii w życie codzienne katechizowanych oraz uzdalniać do działania misyjnego przez świadectwo, dia$\log$ i głoszenie (DOK 194). Najpierw więc - jak podkreśla J. Kostorz - istnieje potrzeba kształtowania świadomości eklezjalnej, a dopiero później zaznajamiania z innymi wyznaniami. Ważna jest konkluzja, którą podsumowuje swe badania wspomniany autor: dokumenty ekumeniczne i katechetyczne jednoznacznie wskazują na trzy zasadnicze aspekty wymiaru ekumenicznego katechezy: poznanie własnego wyznania, poznanie innych wyznań oraz kształtowanie postawy otwartej na ekumenizm ${ }^{40}$.

„Katecheza - jak pisał Jan Paweł II - nie może być pozbawiona wymiaru ekumenicznego" (CT 32). L. Fortino, włoski katechetyk, pisząc o ekumenicznym wymiarze katechezy wyznacza jej charakterystyczne cechy: a) przede wszystkim nauczanie doktryny katolickiej powinno być przejrzyste i integralne, należy unikać wszelkich redukcji, wszelkiego łatwego irenizmu i wszelkiego minimalizmu. Nie można zatem zrezygnować z nauczania, że pełnia prawd objawionych i narzędzi zbawienia znajduje się w Kościele katolickim. Już sama taka prezentacja ma wartość ekumeniczną, o ile prezentowana jest ze szczerym szacunkiem wo-

\footnotetext{
39 Por. TENŻE, Ekumeniczny wymiar, 55-56; W. HANC, Ekumeniczny wymiar katechezy, 205-206.

${ }^{40}$ Por. J. Kostorz, Ekumeniczny wymiar, 82-83.
} 
bec innych chrześcijan. Należy pamiętać o hierarchii prawd w nauce katolickiej (DE 11); b) ważne jest również, by „lojalnie i poprawnie zostały przedstawione inne Kościoły i wspólnoty kościelne" (por. CT 32), unikając historycznych zafałszowań polemiki i sporu. Obiektywizm ten prowadzi do rozróżnienia między wspólnotami będącymi poza pełną komunią z Kościołem katolickim i wskazania elementów, które łączą i dzielą (por. KK 15; DE 3, 15). Nie można także ignorować prezentacji historycznej różnych wspólnot chrześcijańskich - wskazania genezy i czynników pozateologicznych, które przyczyniły się do istniejących podziałów; c) koniecznym elementem wymiaru ekumenicznego są nowe relacje z innymi chrześcijanami, przede wszystkim zastąpienie historycznych polemik wzajemnym otwarciem i dialogiem. Celem tych działań jest formacja nowego typu katolika, mocnego w swej wierze, otwartego na innych braci chrześcijan, aktywnie zaangażowanego zgodnie ze swoją rolą i zdolnością poszukiwania jedności, gotowego dać swe świadectwo w naszych czasach, zatroskanego o niesienie w zgodzie z innymi chrześcijanami orędzia Ewangelii tym, którzy go nie znają. W tym dziele konieczne są zarówno nowe podręczniki oraz metody, jak i dobrze uformowani katecheci, wierni swemu powołaniu ${ }^{41}$.

Oprócz opisanego powyżej wymiaru ekumenicznego katechezy L. Fortino wyróżnił współpracę międzywyznaniową na polu katechezy. Chodzi tu o nawiązywanie nowych relacji między katolikami i innymi chrześcijanami na różnych płaszczyznach w odniesieniu do wspólnych elementów (Pisma Świętego, chrztu, wyznania wiary, Dekalogu, błogosławieństwa itd.). Jest to wyraźne odniesienie do życzenia Jana Pawła II, który pisał, iż „w sytuacji pluralizmu wyznaniowego biskupi mogą uznać za potrzebne, a nawet konieczne w dziedzinie katechezy złączyć wysiłki katolików i innych chrześcijan, co pozwoliłoby uzupełnić zwykłe nauczanie, jakiego jednak koniecznie powinno się udzielić katolikom" (CT 33). Współpraca ta może - zdaniem włoskiego katechetyka konkretyzować się w korzystaniu z pomocy, narzędzi, lokali i osób w jakiejś formie wspólnej katechezy, jednakże z powodu trwałych podziałów katecheza taka jest ograniczona i dla katolików powinna być uzupełniona w Kościele katolickim. Katecheza bowiem nie jest tylko nauczaniem teorii, lecz - i tu znowu odwołanie do papieskiej adhortacji - „wychowaniem w wierze (...) dla wprowadzenia wierzących w pełnię życia chrześcijańskiego” (CT 18), które „polega (...) na wprowadzaniu w całość życia chrześcijańskiego, z pełnym udziałem w sakramentach Kościoła" (CT 33). L. Fortino przypomina, że w niektórych krajach istnieje szczególna forma współpracy, kiedy nauczanie religii chrześcijańskiej jest wspólne dla katolików i niekatolików. Taka forma jednak, choć nie

41 Por. L. Fortino, Ekumenizm, w: C. Bissoli, K. MisiaszeK (red.), Słownik katechetyczny, Warszawa 2007, 238-239. 
stanowi prawdziwej katechezy, ma znaczenie ekumeniczne, ponieważ lojalnie przedstawia doktrynę chrześcijańską. I znowu pojawiają się papieskie słowa: „Tam, gdzie okoliczności zmuszają do takiego nauczania, należy w inny sposób i ze znacznie większą jeszcze sumiennością zapewnić prawdziwie katolicką katechezę" (CT 33; zob. DOK 198) ${ }^{42}$. Wierność własnemu wyznaniu jest podstawą działań ekumenicznych i tylko ona gwarantuje, że osoby odpowiedzialne za wychowanie młodych nie zagubią się w rozlicznych meandrach współczesnych propozycji pedagogiczno-religijnych.

\section{Bibliografia}

BieHl P., Religionsdidaktische Konzeptionen, w: G. Bitter, R. Englert, G. MiLLER, K.E. NIPKOw (red.), Neues Handbuch religionspädagogischer Grundbegriffe, München 2002, s. 440-446.

ChaŁUPNIAK R., Między katecheza a religioznawstwem. Nauczanie religii katolickiej w szkole publicznej w Niemczech w latach 1945-2000 (Opolska Biblioteka Teologiczna 79), Opole 2005.

Dross R., Profane Religionspädagogik, w: N. Mette, F. Rickers (red.), Lexikon der Religionspädagogik, t. II, Neukirchen-Vluyn 2001, k. 1565-1568.

GöPfert H., Religionsunterricht und weltanschauliche Pluralität. Problem und Lösungsvorschlag für den Primarbereich, Stuttgart - München 1974.

Grethlein Ch., Religionspädagogik, Berlin - New York 1998.

Hanc W., Ekumeniczny wymiar katechezy, „Studia Oecumenica” 4 (2004), s. $183-207$.

Hemel U., Religionspädagogik im Kontext von Theologie und Kirche, Düsseldorf 1986.

Hilger G., Leimgruber S., Ziebertz H.G., Religionsdidaktik. Ein Leitfaden für Studium, Ausbildung und Beruf, München 2001.

JaskóŁa P., Ekumenizm w katechezie, w: R. ChaŁupniak, J. Kochel, J. Kostorz, W. SpYra (red.), Wokót katechezy posoborowej (Opolska Biblioteka Teologiczna 70), Opole 2004, s. 73-76.

Kostorz J., Ekumeniczny wymiar posoborowej katechezy w Polsce (Opolska Biblioteka Teologiczna 98), Opole 2007.

Lotт J. (red.), Religion - warum und wozu in der Schule?, Weinheim 1992.

Łabendowicz S., Katecheza - wymiar ekumeniczny, w: C. Rogowski (red.), Leksykon pedagogiki religii. Podstawy - koncepcje - perspektywy, Warszawa 2007, s. 272-274. 
Noormann H., Becker U., Trocholepczy B. (red.), Ökumenisches Arbeitsbuch Religionspädagogik, Stuttgart 2004².

Rogowski C., Koncepcje katechetyczne po Soborze Watykańskim II, Lublin 1997.

Rogowski C., Wychowanie ekumeniczne, w: TENŻE (red.), Leksykon pedagogiki religii. Podstawy - koncepcje - perspektywy, Warszawa 2007, s. 859-861. 